\title{
Editorial
}

\section{The Future of CBE-Life Sciences Education}

\author{
William B. Wood, Editor-in-Chief
}

\author{
Department of Molecular, Cellular and Developmental Biology, University of Colorado, Boulder, CO 80309
}

On August 1, I had the honor of becoming Editor-in-Chief of Cell Biology Education, replacing co-editors Sarah (Sally) Elgin and Malcolm Campbell. Sally and Malcolm have done a tremendous job. Over the past three years, they have built what was a wonderful idea but a struggling operation into a respected educational journal that ASCB can take great pride in. $C B E$ now has over 5,000 registered subscribers and a broad base of contributors, including ASCB members as well as other scientists, teachers, and educators from several disciplines. I thank and salute Sally and Malcolm for their highly effective stewardship, and I will do my best to maintain their high standards and continue the pursuit of their vision for the journal.

Cell Biology Education is a unique publication. It is written by and for biologists about educational issues, but with a mission: helping its contributors and readers to think more deeply about the way they teach and to improve their teaching skills. Several other journals publish new lab descriptions, teaching tips, and so on, but Cell Biology Education goes further, asking contributors to approach their teaching as they do their research. This means not just experimenting with new approaches but collecting evidence to evaluate their effectiveness (Handelsman, et al., 2004). Articles on development of new courses or labs are not accepted without some assessment data to demonstrate how well the course worked in terms of student learning gains (not simply student approval and instructor satisfaction). To help educate potential contributors about how to do assessment, which is a new endeavor for many of us, the journal has published several helpful and informative articles on how to do it effectively (e.g., Sundberg, 2002; Dancy and Beichner, 2002).

Cell Biology Education now has opportunities to grow in circulation, scope, and influence, and the journal will make a few changes to help this happen. Its goal from the start has been to serve all biologists, but some potential contributors outside the field of cell biology have found the current name too restrictive. Beginning with the Spring 2006 issue, the journal's name will become CBE-Life Sciences Education, signaling our intention to publish work from other areas but retaining the familiar " $C B E$ " and clear identification with
ASCB. For the same purposes, we have recently added several respected biologist-educators from other areas to the editorial board. We expect that they will help to increase the number and scope of submissions, which in turn should increase and broaden our readership. Finally, exploratory talks are under way with a few other biological societies that may be interested in allying their efforts in education with ours in some way, making CBE an umbrella gateway to the biology education literature.

Two things will not change! One is the free availability of the journal online to all readers. The other is the admirable balance that the journal has achieved, on its diverse and discriminating editorial board and in its diversity of features and articles. CBE-LSE will continue to be written by and to serve professionals engaged in biology teaching in all environments, including faculty at large research universities who teach but do not view teaching as their primary mission, as well as those whose teaching is the major focus of their careers, in primarily undergraduate institutions, museums and outreach programs, junior and community colleges, and K-12 schools. All of us have successes to report and problems to solve that can benefit from the broad forum that the journal provides, and one of our goals will be to continue bringing these diverse educators together in a concerted effort to improve education in biology. I urge you to use the journal and to help spread awareness of the unique resources it provides. Consider reporting your own educational innovations in these pages. CBE-LSE will continue to be your journal, and with your help and support it will be an increasingly important force in life sciences education.

\section{REFERENCES}

Dancy, M., and Beichner, R. (2002). But are they learning? Getting started in classroom evaluation. Cell Biol. Educ. 1, 87-94.

Handelsman, J., Ebert-May, D. Beichner, R., Bruns, P., Chang, A., DeHaan, R., Gentile, J., Lauffer, S., Stewart, J., Tilghman, S.M., and Wood, W.B. (2004). Scientific teaching. Science 304, 521-522.

Sundberg, M. (2002). Assessing student learning. Cell Biol. Educ. 1, 11-15.
DOI: $10.1187 /$ cbe.05-08-0106

Address correspondence to: William B. Wood (wood@colorado. edu). 